\title{
Influence of Internet-based Social Big Data on Personal Credit Reporting
}

\author{
Meng Li1), Zhang Shuang2), Wang Fuqiang3)
}

\begin{abstract}
With the advent of the era of big data, the connotation of Credit investigation in China has gradually shifted from traditional data to social big data. The sources of credit data are not limited to traditional data, such as credit data; It also includes data on network behavior based on Internet transactions. The scene of credit investigation also extends from the financial industry to economic and social life. Based on the traditional credit analysis model, this paper puts forward a new network behavior credit analysis model by replacing "mortgage" with "social". Through data collection, data model, data service and other links, this paper proves that big data of network behavior can cover all credit investigation elements and can be used as a data source for personal credit analysis, with very high integrity. Among them, social network big data is a very important data source and occupies a high weight. This paper adopts the information research method, collects, processes and collates the social network big data, personal credit investigation and other information, constructs the "5C" credit analysis method of network behavior, and studies the personal credit investigation of the social network big data by combining the examples of Domestic Internet giants Tencent and Ali, and adopts the tabling method and cobweb map, etc. The network behavior credit analysis model proposed in this paper makes full use of the big data of social network to promote the development of personal credit investigation business and provides meaningful and valuable Suggestions for the government and industry.
\end{abstract}

Keywords: Personal, Credit Information, Big Data, Social Network, Financial Industry

\section{Introduction}

With the accelerated construction of China's credit system and the rapid improvement of the nation's credit awareness, China's credit society is accelerating. Among them, the construction of the credit information system is an important part of building a credit society. With the rapid development of big data technology and Internet technology, the connotation and extension of credit information has also greatly expanded. The sources of credit information

Received(March 16, 2020), Review Result(1st: April 14, 2020, 2nd: June 01, 2020), Accepted(June 25, 2020)

1) (Professor, Corresponding Author) School of Business Administration, Wuhan Business University email: mengmeng321@163.com

2) (Professor) School of Business Administration, Wuhan Business University email: 6307552687@qq.com

3) (Professor) School of Business Administration, Wuhan Business University email: fuqiangchina@163.com 
include not only traditional data, such as credit data, but also third-party data based on Internet transactions and Internet socialization. Credit application scenarios are not limited to the financial industry, but are widely used in all aspects of economic and social life. There is no doubt that the era of big data development in the credit reporting industry has come.

Modern personal credit reporting is accompanied by the development of personal credit business in the financial system. From the experience of developed countries in Europe and America, the credit reference system has become an important infrastructure for modern economic operation, especially in the United States. Due to the emergence of credit scores, an automated and batch loan approval process can be realized, which greatly promotes consumer credit. development of. In the United States, the credit information of the credit reporting industry is not only used as the main reference for financial institutions to issue consumer credit to individuals, but also gradually becomes the basis for leasing companies to investigate the credit status of individual users, shopping malls and supermarkets issue shopping cards to customers, and public service companies to open services. , Has become an important reference for employers to understand the conduct of applicants. In recent years, the three major personal credit bureaus have also gradually used big data to develop markets and marketing products. For example, Experian, as the world's largest credit bureau, has great advantages in terms of data resource application, depth and breadth of analysis. In terms of data resources, Experian has data of 890 million consumers and 1.03 billion enterprises (mainly small and micro enterprises) worldwide, and many of them are exclusive data sources, such as user public data, insurance data, and credit Data, medical data, rental data, car data, etc.

At present, the exploration of big data credit reporting by foreign mainstream credit reporting agencies is still in the testing and launching stage, and business models and application scenarios are still needed to verify and improve, but it is undeniable that big data credit reporting is the direction of the credit reporting industry. Drawing on foreign big data credit reporting, there are two points worth noting: First, in the data collection link, you need to choose big data that is strongly related to credit risk, such as: rent data, public payment data, telecommunications data, and payment data; In the process of data usage, it is necessary to focus on protecting the rights and privacy of consumers, and to fully take care of consumers' subjective feelings.

At present, there has been some research on big data personal credit information at home and abroad. It has analyzed from different angles of data collection, data models, and data services. It also has research and suggestions on data supervision and protection of personal privacy. Luo Zhenzhen[1] put forward in the "Individual Credit Information Research Based on 
Social Network Data": Social network data credit information has been adopted abroad, especially in small loans, and has achieved good results, and my country is also actively exploring. Feng Wenfang and Li Chunmei[2] proposed in the "Exploration of the Construction of Big Data Credit Reporting System in the Internet + Times" that the credit evaluation based on big data needs to be examined through multi-dimensional credit information, including not only financial indicators such as cash flow, but also address information. , Behavior data, social relations and other indicators under semi-structured and unstructured data. Dong Yuanxiang and Cheng Xin[3] used the three-dimensional credit theory as the theoretical basis in the "Building of Personal Credit Evaluation System under the Background of Big Data", based on big data technology, through the analysis of Internet finance, social networks, and online behavior data, built a The new personal credit evaluation system, the original traditional credit evaluation method can no longer adapt to this new personal credit evaluation system.

With the continuous expansion of the Internet user group, social networks and social applications have also continued to spread. According to the "2018 China Social Application User Behavior Research Report" released by CNNIC in 2019, China's social network market has seen diversification and differentiation of social applications, High proportion and other characteristics. Social applications can generally be divided into instant communication tools, integrated social applications, and vertically subdivided social applications. The instant messaging tools are mainly represented by Tencent's QQ and WeChat, and mainly meet the social needs of users for real-time interactive communication, with an average utilization rate of about 90\%; integrated social applications, with QQ space and WeChat circle of friends as the main representatives, are based on real-time The social services derived from communication tools are focused on acquaintances, and the utilization rate of netizens is $85.8 \%$ and $67.5 \%$ respectively. With the continuous growth of the size of social network users, the proportion of online social users in the overall netizens continues to increase, and online social networking becomes users the main purpose of the Internet.

Nowadays, "socialization" has become the development direction of all Internet applications, which also makes the entire society enter the "pan-social" era, it makes people and people, people and organizations, organizations and organizations are ubiquitous. Modern life is more and more dependent on the Internet, and personal credit is increasingly important to economic and social life. Based on the perspective of system ecology, this article quantifies and systematically studies social network big data from the aspects of data collection, data model, data service, etc. Personal credit. 


\section{The Formation of Big Data Personal Credit}

The earliest organization that proposed the era of "big data" was the well-known consulting firm McKinsey. According to McKinsey research, the use of big data can produce significant social benefits in all walks of life. So, how to define big data? Baidu Encyclopedia defines big data as: a collection of data that cannot be effectively collected, cleaned, and processed by conventional software tools in a short period of time. It is a large data volume, high growth rate, and diverse information assets. What is big data credit reporting? Big data technology is becoming more and more widely used in the financial field, and big data credit reporting has also been paid more and more attention. Paper[4] defined "Big Data Credit Reporting from the Connotation and Composition of Credit" to define the essence of big data credit reporting is to use the big data technology as a means to help people record and judge credit value through the Internet, and comprehensively describe integrity and compliance Degree and compliance, big data credit has injected rich multi-dimensional credit data into the credit industry, providing more convenient and accurate credit information services, helping people without physical capital to find their own credit capital and value to realize their own aims. In essence, big data credit reporting is to make full use of the advantages of big data technology in credit reporting activities, such as large data processing volume, wide data dimensions, and dynamic display of data status, etc., in the business scope allowed by laws and regulations Within this, data information is collected, cleaned, and analyzed through big data technology, and services are provided to users through new perspectives and methods.

Big data has the characteristics of $4 \mathrm{~V}$, large data volume (Volume), wide variety of data (Variety), fast data processing speed (Velocity), and low data value density (Value). Due to the $4 \mathrm{~V}$ characteristics of big data, the processing flow of big data credit reporting is much more complicated than traditional credit reporting services. For big data credit reporting, the most basic role of credit reporting agencies is to disperse the fragmented local information in different credit institutions into global information with a complete view effect, dig out risk information from it, and help solve the problem of information in the transaction process. Complete questions to reduce risks, reduce transaction costs, and help business organizations make more effective decisions. Big data technology helps to process more dispersed, fragmented, and underlying data into more complete global information, and more effectively reduces information asymmetry. Liu Xinhai[5] defined the process of big data credit reporting in "Credit Information and Big Data" as: data collection, data processing, data analysis and 


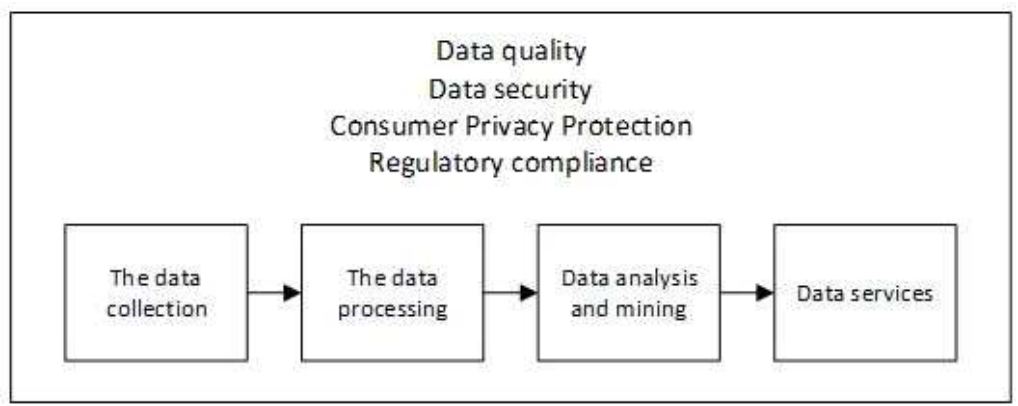

[Fig. 1] Big Data Application Process

Big data is bringing about a revolution in the information society[6][7]. The extensive use of large amounts of structured and unstructured data requires us to reconsider existing IT models. The huge data requires us to carry out operations such as stripping, sorting, categorizing, modeling, and analyzing. Then we start to establish the dimensions of data analysis and analyze the data through different dimensions to finally get the desired data and information. For the data collection, data processing, data analysis and mining and data services in the big data credit reporting process, there are currently mature technology implementation methods[8].

The credit information system is the infrastructure of the entire social finance and even the economy. Although the scale of the industry is small, the spillover society has a great impact. After hundreds of years of development, the credit information industry is currently evolving from a traditional financial risk service provider to a modern economic and social information service provider. Credit reporting and big data are genetically linked. Several of the world's largest credit reporting agencies claim to be big data companies. The core asset of credit reporting agencies is data, and credit reporting products and services are among the best scenarios for financial big data technology. One. Credit information is an area where information technology and finance intersect. It coincides with the rise of Internet finance, the arrival of the era of big data, and the growth of "Internet +". Governments, financial institutions, Internet companies, big data companies, the public, and media It has invested unprecedented enthusiasm and has high hopes.

In response to the single service scenario of traditional credit reporting industry, due to the wide range of data sources and rich data models, big data credit reporting can serve more application scenarios. In addition to the credit business in the financial field covered by the traditional credit reporting business, it can also serve the economy Provide more services in the 
field and social field. Taking the United States as an example, [Table 1] illustrates the differences between the traditional credit risk assessment system and the credit risk assessment system based on big data[9].

[Table 1] Comparison between Traditional Credit Risk Assessment System and Big Data-based Credit Risk Assessment System

\begin{tabular}{|c|c|c|}
\hline & $\begin{array}{c}\text { Traditional credit risk assessment } \\
\text { system }\end{array}$ & $\begin{array}{c}\text { Comparison of credit risk assessment based } \\
\text { on big data }\end{array}$ \\
\hline $\begin{array}{c}\text { Representative } \\
\text { enterprise }\end{array}$ & FICO & ZestFinance \\
\hline Serving people & People with rich credit history & People who lack or have no credit history \\
\hline Data Format & Structured data & Structured data, unstructured data \\
\hline type of data & Credit data & Credit data, network data, social data \\
\hline Theoretical basis & Logistic regression & Machine learning \\
\hline $\begin{array}{c}\text { Variable } \\
\text { characteristics }\end{array}$ & $\begin{array}{c}\text { Repayment history, amount, loan } \\
\text { type }\end{array}$ & $\begin{array}{c}\text { Traditional data, IP address, email name, } \\
\text { form filling habits }\end{array}$ \\
\hline $\begin{array}{c}\text { Data Sources } \\
\text { Number of } \\
\text { variables }\end{array}$ & Third-party data and local data & Third-party data and borrower data \\
\hline
\end{tabular}

In 2016, Wu Jingmei concluded that China will form three major credit information source systems in the future: the first is the financial credit information system, mainly the financial information data accumulated by the People's Bank Credit Information Center, such as credit, guarantee, mortgage and other data; second It is a public credit information system, a credit information system mainly based on government department supervision data and administrative data. With the development of government affairs online and information sharing, a national data system will be formed; the third is the commercial credit information system, With Internet transactions, Internet socializing, etc. as the main content. In fact, almost all big data related to people's social activities can be used for credit analysis, because people's credit is reflected in social activities that are present all the time. According to the practice of personal credit business at home and abroad, in addition to the traditional financial industry big data, government network big data, communication network big data, Internet big data, etc. are more suitable for credit analysis. Internet big data, such as the big data generated by Internet transactions and Internet socialization, is a blue ocean that has not yet fully tapped the value in the domestic credit reporting industry. The domestic Internet giants, Ali and Tencent, rely on their Internet big data to enter the credit investigation industry. This article focuses on the value and mode of social network big data in the Internet big data to the credit reporting industry. Strictly speaking, telecommunications big data also belongs to social network big data, 
but the focus of this study is Internet-based social big data.

\section{Social Network Big Data Personal Credit Theory Analysis}

\subsection{Definition of Social Network}

Maslow's theory of needs hierarchy shows that human needs are divided into five categories from low to high, namely: physiological needs, safety needs, social needs, respect needs and self-realization needs. Satisfaction of social needs is achieved through social networks. Social networks are composed of a large number of nodes and social relationships. Nodes refer to individuals or organizations. Social relationships are a kind of connection between nodes, such as values, ideals, concepts, and finance. Communication, friendship, blood relationship, etc. Through these social relationships, various nodes (individuals or organizations) are connected in series to form a social network[10-12]. The realization of social networks needs to be achieved through tools. According to the "2016 China Social Application User Behavior Research Report" released by CNNIC (2017), the social applications on the market are classified, see [Table 2].

[Table 2] Social Application Classification

\begin{tabular}{|c|c|}
\hline classification & application \\
\hline Instant messaging social application & QQ WeChat, Momo, Ali Want, QT Voice, etc. \\
\hline Comprehensive social applications & QQ Space, Sina Weibo, WeChat Moments, etc. \\
\hline Picture Video Social & Beauty, second, Youku, etc. \\
\hline Marriage & $\begin{array}{c}58 \text { Making friends, catching up with marriage, Shiji } \\
\text { Jiayuan, etc. }\end{array}$ \\
\hline Community social & $\begin{array}{c}\text { Baidu Post Bar, Douban, Tianya Community, Zhihu, } \\
\text { etc. }\end{array}$ \\
\hline Workplace social & Maimai, LinkedIn, hiring secretary, etc. \\
\hline
\end{tabular}

Users can carry out social activities through social applications. Along with the process of users' social networking, massive data will be generated, and these data will become interesting and valuable through big data technology. Data mining on these social network relationships to obtain more valuable data has become a popular technology in the field of big data. Through the analysis of social network big data, you can better understand the psychology and behavior of consumers, and get and consume better Big data has a great influence on the traditional way of working and thinking. It can be said that big data is changing our lives. In the field of social networks, big data will also bring some changes:

First, social big data marketing, through big data technology to analyze the user's social 
data, the merchant can accurately grasp the user's psychology and expectations, which can reasonably guide the user's consumption behavior.

Second, social big data evaluation. Through big data technology to analyze users' social data, merchants can more accurately carry out brand promotion and product push to users, and even analyze the information generated in this process to master more Market opportunities and market demand.

Third, social big data prediction. By analyzing the user's social data through big data technology, the user's behavior can be predicted and analyzed. The merchant can adjust the original production and marketing plan accordingly. The prediction function is the core value of big data.

\subsection{The Value of Social Network Big Data to Personal Credit Reporting}

Regarding the research of social networks, the current research is mainly carried out from the perspective of communication and sociology. After long-term exploration, researchers have found that social networks also have the convenience of applying big data[11] and authenticity[12-14]. Social network data is born big data. The combination of social networks and big data is a natural result. For example, in the British TV series "Black Mirror" (Black Mirror), through big data and artificial intelligence technology analysis, we do not know on the Internet The huge amount of social information left unconsciously, combined with analysis and interpretation, can copy another one to a certain extent. Another example, recently the big data "killing" incident of the e-commerce platform exposed also analyzes users' social networking and online trading behaviors through big data technology, and conducts "price discrimination" against users.

Social networks can accumulate social credit, thereby promoting social and economic development. Social networks can enable people to accumulate social capital quickly, thereby greatly reducing the cost of financial transactions, which has a fundamental role in financial transactions. In fact, the social capital that can be accumulated between people is social credit, and the value of social networks to social credit can be intuitively proven from Bangladesh's "Village Bank" (Graymin Bank). Grameen Bank specializes in providing loan services to the poor. The lenders can form a "unity group" of 6 to 8 people to supervise each other's repayment situation. If someone in the group is overdue, the entire group is responsible. In fact, relying on " The social network of the "Unity Group" has generated social credit, so that people without credit records can enjoy credit services. In fact, many financial innovation 
products (such as factoring business) are in-depth understanding of the relationship between people and people, people and enterprises, enterprises and enterprises and other economic and social subjects, so as to provide Winning financial products.

The combination of social networks and big data will produce higher value for social credit[15]. We can analyze personal credit based on big data accumulated on social networks and use it to recommend wealth management products. The establishment of a large database is a long-term and huge project. At present, Ali and Tencent have only used some of the most basic data to develop unique financial products. If Alibaba and Tencent fully establish a large social database in the future, a new financial ecology will be built.

Specifically, the value of social network big data to personal credit reporting can be considered from the following aspects:

First, from the perspective of data collection, social network big data is natural and the most authentic big data, which can most truly reflect a person's behavior and psychology, and can also best reflect a person's credit status. For example, a person's browsing history, chat history, and payment history are full of daily life trajectory, and it is difficult to deliberately falsify.

Second, from the perspective of covering people, according to the 43rd Statistical Report on Internet Development in China released by CNNIC, as of the end of 2019, the number of Internet users in China reached 827 million, of which the number of timely communication users reached 792 million. The proportion is as high as $95.6 \%$. It can be seen that the number of social network users is extremely high, and the realization of personal credit through social network big data is of great significance for improving the coverage of credit groups and for the development of inclusive finance.

Third, from the perspective of application scenarios, data models of various life scenarios can be established based on social network big data, thereby providing richer application scenarios. In particular, the accuracy of big data association evaluation makes social data have extremely high-risk control value. Many Internet giants have seen this opportunity. For example, Ali's acquisition of Weibo is to obtain a large amount of social information to create a risk control model to reduce decision risk. , Neo company uses the user's social information on the LinkedIn website (Linkedin), such as the number of contacts, quality and frequency of activities, to create a model to determine whether the user's working status is true.

\section{Quantitative Analysis of Personal Credit Information of Social Network Big Data}

According to the traditional "5C" credit analysis model, the elements of credit evaluation 
include: quality, capability, capital, mortgage, and conditions.

\subsection{Analysis of the Development of Personal Credit Reporting in My Country}

For the 8 institutions involved in the "Notice on Doing a Good Job in Personal Credit Reporting Business" issued by the People's Bank of China, this chapter compares and analyzes the company's background, data sources, credit information products, and service scenarios. See the [Table 3].

[Table 3] Comparison of 8 Pilot Institutions for Personal Credit Investigation in My Country

\begin{tabular}{|c|c|c|c|c|}
\hline $\begin{array}{l}\text { company } \\
\text { name }\end{array}$ & $\begin{array}{l}\text { company } \\
\text { background }\end{array}$ & Data Sources & $\begin{array}{l}\text { Credit } \\
\text { information } \\
\text { products }\end{array}$ & Service scenario \\
\hline $\begin{array}{l}\text { Sesame } \\
\text { Credit }\end{array}$ & $\begin{array}{l}\text { Relying on Ali } \\
\text { Group }\end{array}$ & $\begin{array}{l}\text { E-commerce platform, } \\
\text { Internet financial } \\
\text { platform, Alibaba } \\
\text { Cloud, interactive } \\
\text { entertainment platform }\end{array}$ & $\begin{array}{l}\text { Credit } \\
\text { score-Sesame } \\
\text { credit }\end{array}$ & $\begin{array}{l}\text { Finance, e-commerce } \\
\text { shopping guide, } \\
\text { community social } \\
\text { networking, O2O, } \\
\text { travel, } \\
\text { accommodation, life, } \\
\text { etc. }\end{array}$ \\
\hline $\begin{array}{l}\text { Tencent } \\
\text { Credit }\end{array}$ & $\begin{array}{l}\text { Relying on } \\
\text { Tencent Group }\end{array}$ & Social platforms & $\begin{array}{l}\text { Anti-fraud, credit } \\
\text { evaluation, } \\
\text { personal credit } \\
\text { application } \\
\text { platform, risk } \\
\text { warning, } \\
\text { post-loan } \\
\text { management }\end{array}$ & $\begin{array}{l}\text { Commercial banks, } \\
\text { consumer finance } \\
\text { companies, small } \\
\text { loans and P2P } \\
\text { companies, insurance } \\
\text { companies, financial } \\
\text { service companies }\end{array}$ \\
\hline $\begin{array}{l}\text { Qianhai } \\
\text { Credit } \\
\text { Information }\end{array}$ & $\begin{array}{l}\text { Relying on Ping } \\
\text { An Group }\end{array}$ & $\begin{array}{l}\text { Overdue credit, } \\
\text { negative administrative, } \\
\text { long loan, fraud }\end{array}$ & $\begin{array}{l}\text { Credit risk } \\
\text { products }\end{array}$ & $\begin{array}{l}\text { Credit, car rental, car } \\
\text { loan, anti-fraud } \\
\text { services, identity } \\
\text { verification services, } \\
\text { consulting services } \\
\end{array}$ \\
\hline $\begin{array}{l}\text { Pengyuan } \\
\text { Credit } \\
\text { Information }\end{array}$ & $\begin{array}{l}\text { Old credit } \\
\text { information } \\
\text { company }\end{array}$ & $\begin{array}{l}\text { Citizenship information, } \\
\text { bank identity } \\
\text { information, biometric } \\
\text { information, risk } \\
\text { information, long loan } \\
\text { information }\end{array}$ & $\begin{array}{l}\text { Anti-fraud } \\
\text { products }\end{array}$ & $\begin{array}{c}\text { Identity } \\
\text { authentication } \\
\text { services, anti-fraud } \\
\text { services, credit, } \\
\text { leasing, job search, } \\
\text { marriage, precision } \\
\text { marketing }\end{array}$ \\
\hline $\begin{array}{c}\text { Credit } \\
\text { Integrity }\end{array}$ & $\begin{array}{l}\text { Old credit } \\
\text { information } \\
\text { company }\end{array}$ & $\begin{array}{l}\text { Identity, education, } \\
\text { occupation, } \\
\text { communication }\end{array}$ & $\begin{array}{l}\text { Identity } \\
\text { verification } \\
\text { products }\end{array}$ & $\begin{array}{l}\text { Traditional Finance, } \\
\text { Internet Finance, } \\
\text { Internet Insurance, } \\
\text { Government }\end{array}$ \\
\hline
\end{tabular}


Vol.6, No.7, July 31 (2020), pp.39-57 http://dx.doi.org/10.47116/apjcri.2020.07.05

\begin{tabular}{|c|c|c|c|c|}
\hline & & & & $\begin{array}{l}\text { Agencies, Industry } \\
\text { Associations, } \\
\text { Academic Units, } \\
\text { Firms }\end{array}$ \\
\hline $\begin{array}{l}\text { Zhong } \\
\text { Zhicheng }\end{array}$ & $\begin{array}{l}\text { Old credit } \\
\text { information } \\
\text { company }\end{array}$ & $\begin{array}{l}\text { Letter, consumption, } \\
\text { credit, justice }\end{array}$ & $\begin{array}{c}\text { Identity } \\
\text { authentication } \\
\text { products }\end{array}$ & $\begin{array}{c}\text { Credit card } \\
\text { application, Internet } \\
\text { finance, consumer } \\
\text { finance, small and } \\
\text { micro loans }\end{array}$ \\
\hline Koala Credit & $\begin{array}{l}\text { Rely on Lakala } \\
\text { and many other } \\
\text { companies }\end{array}$ & $\begin{array}{l}\text { Credit activity, contract } \\
\text { performance, credit } \\
\text { history, identity traits, } \\
\text { credit consumption } \\
\text { ability }\end{array}$ & $\begin{array}{l}\text { Pre-loan } \\
\text { anti-fraud } \\
\text { analysis }\end{array}$ & $\begin{array}{l}\text { Credit wealth } \\
\text { management, } \\
\text { insurance, } \\
\text { employment, car } \\
\text { rental, } \\
\text { accommodation, } \\
\text { tourism, rental } \\
\text { housing, catering, } \\
\text { intermediary services }\end{array}$ \\
\hline $\begin{array}{l}\text { China Road } \\
\text { Credit }\end{array}$ & $\begin{array}{l}\text { Via short } \\
\text { message }\end{array}$ & $\begin{array}{l}\text { Personal credit records, } \\
\text { performance capabilities, } \\
\text { identity attributes, social } \\
\text { relationships, trading } \\
\text { behavior }\end{array}$ & $\begin{array}{l}\text { Risk monitoring } \\
\text { during loan }\end{array}$ & $\begin{array}{l}\text { Credit financing, } \\
\text { insurance, renting }\end{array}$ \\
\hline
\end{tabular}

It can be seen from the above table that the data sources and credit information products of the eight pilot institutions have their own strengths and strong complementarities. It is in this case that on May 23, 2018, Baixing Credit Information was officially launched in Shenzhen. The inauguration became the only market-oriented personal credit reporting agency approved by the central bank and the only one with a personal credit business license.

From the perspective of the shareholder structure and cooperative units of Baixing Credit Rating, Baixing Credit Rating is a typical big data personal credit reporting company, which integrates the most extensive and valuable personal credit reporting big data in China, and is China's personal credit reporting "National Enterprise" in the industry. First, its personal credit reporting data sources are more extensive. In addition to traditional financial data, it also introduces the Internet giant's social network big data, which will greatly promote the coverage of the "credit reporting gap" population. People who have no credit records in traditional credit institutions, but most of them have Internet social or Internet transaction records. These people are definitely the focus of relevant institutions in the future. Second, the data model of their personal credit information will be more abundant. Financial credit data and Internet social and transaction big data can further optimize existing models, reduce default risk, and enable differentiated pricing to enable more users to enjoy financial services at lower borrowing 
costs; The letter fills the gap of personal credit reporting for Internet finance and small and micro finance. The long-term lending situation caused by the isolated island of information will be broken, and the bank lending market of the central bank credit information center can also form an effective complementation, making the personal credit society more perfect. To greatly increase the cost of being a "deadbeat".

\subsection{Network "5C" Credit Analysis Model}

According to the traditional "5C" credit analysis model, the elements of credit evaluation include: quality, capability, capital, mortgage, and conditions. The purpose of this article is to analyze the value of social network big data for personal credit based on network behavior. Since the traditional "5C" model does not consider the characteristics of network behavior, we need to transform it without changing its completeness. After analysis, the four elements of quality, ability, capital, and condition can all be reflected by network behavior, but the mortgage element is difficult to be reflected by network behavior. Therefore, based on the following considerations, we can replace the "mortgage" element with a "social" element. Since social network big data is of great value to personal credit reporting, the self's credit concept will be affected by social relationships. The personal social relationship can be used as a mortgage, and the social relationship can be used as a "soft" mortgage. Therefore, From a practical point of view, it is reasonable to replace the "mortgage" element with the "social" element. We call this new " $5 \mathrm{C}$ " model the network behavior " $5 \mathrm{C}$ " credit analysis model, which includes: quality, ability, capital, socialization, conditions and other elements.

\subsection{Data Analysis}

The big data of network behavior comes from the network behavior of users using Internet applications or products. Among them, the big data of social network comes from the network social behavior of using network social applications or products[16]. Ali and Tencent have the largest amount of network behavior data. Alibaba's network behavior big data mainly comes from users using its product line. Alibaba's biggest data source is the online transaction big data generated by Taobao and Tmall, mainly as follows:

(1) E-commerce platform. Alibaba's core data platform provides a large amount of transaction information big data, including Taobao, Tmall, Juzui, AliExpress, domestic wholesale platform 1688, cross-border wholesale platform Alibaba, etc.;

(2) Internet finance platform. Including Alipay as the core payment business, Alibaba's small 
loan-based micro-loan business, Mall-based Finance Guarantee Co., Ltd.-based guarantee business, and financial retail (finance + insurance) business. Through this platform, Ali has accumulated a large amount of financial big data;

(3) Cloud business. Alibaba Cloud has gradually developed into a comprehensive cloud service platform, which also provides Alibaba with a large amount of user behavior big data;

(4) Interactive entertainment business. It is composed of services such as film and television, games, music, and reading. This is Ali's non-core business, which provides diversity for Ali to describe user portraits. Tencent's network behavior big data is mainly generated through its network application products. Tencent's largest data source is online social big data generated by WeChat and QQ mainly as follows:

(1) Social products: including QQ, Tencent RTX, TM, QQ computer housekeeper, TT browser, QQ whirlwind, QQ mailbox, QQ software management, QQ video, enterprise QQ online, enterprise QQ office version, QQ Pinyin, Foxmail, etc.;

(2) Online media: including Tencent, Soso, etc.;

(3) E-commerce platform: including Tenpay, Paipai, QQ movie tickets, etc.;

(4) Wireless Internet value-added services: including WeChat, mobile QQ, mobile Tencent, mobile QQ games, super QQ mobile QQ music, etc.;

(5) Internet value-added products: including QQ members, QQ space, QQ show, QQLive, QQ music, urban masters, alumni, etc.;

(6) Interactive entertainment products: including large-scale MMOG, Q-version MMOG, FPS, gaming platforms, tabletop games, casual games, Tencent page games, etc.

After the above analysis, Alibaba and Tencent's network behavior big data sources are very rich, covering most of the network behavior, but their data has its own focus. Alibaba has a monopolistic advantage in online transaction big data. Tencent has a social network Big data is extremely advantageous.

We classify the above-mentioned network behavior according to the network behavior " $5 \mathrm{C}$ " credit analysis model, as follows.

[Table 4] Classification of Network Behavior According to the "5C" Credit Analysis Model of Network Behavior

\begin{tabular}{|c|c|c|}
\hline Credit factor & Element description & Network behavior \\
\hline quality & $\begin{array}{c}\text { Personal quality, } \\
\text { willingness to repay }\end{array}$ & $\begin{array}{c}\text { Instant messaging, search engines, online news, online } \\
\text { videos, online music, online games, online literature, live } \\
\text { webcasts, Weibo, online education }\end{array}$ \\
\hline ability & $\begin{array}{c}\text { Personal ability, } \\
\text { repayment ability }\end{array}$ & $\begin{array}{c}\text { Online shopping, online games, travel booking, online } \\
\text { order delivery, online live broadcast, online education, }\end{array}$ \\
\hline
\end{tabular}




\begin{tabular}{|c|c|c|}
\hline & & Internet banking \\
\hline capital & $\begin{array}{l}\text { Personal financial } \\
\text { resources, repayment } \\
\text { financial resources }\end{array}$ & Online payment, online banking, Internet banking \\
\hline $\begin{array}{c}\text { Social } \\
\text { (mortgage) }\end{array}$ & Personal social relations & $\begin{array}{l}\text { Instant messaging, online games, webcasts, Weibo, online } \\
\text { education, short videos }\end{array}$ \\
\hline condition & $\begin{array}{l}\text { The impact of the } \\
\text { economic environment } \\
\text { on individuals }\end{array}$ & $\begin{array}{l}\text { Online shopping, travel booking, online order delivery, } \\
\text { online express or special car, online taxi, Internet banking }\end{array}$ \\
\hline
\end{tabular}

Through the above table analysis, it is found that network behavior can cover all dimensions of the " $5 \mathrm{C}$ " model, indicating that it is feasible to conduct personal credit analysis based on network behavior big data. After classifying network behaviors according to the " $5 C^{\prime \prime}$ model, we next need to analyze how and how the data generated by these network behaviors contributes to credit analysis. To simplify the study, we make the following assumptions:

(1) The higher the usage rate of network behavior, the higher the amount of data generated;

(2) The higher the proportion of network behavior usage time, the higher the amount of data generated;

(3) According to one of the big data $4 \mathrm{~V}$ characteristics-large data size, the larger the amount of data generated by network behavior, the greater the weight of data representing the network behavior, the greater the value of credit analysis. Based on the above assumptions, we build the following model:

Data weight $=$ usage rate $\mathrm{x}$ usage time ratio $\times 100(4-1)$

According to the 43rd <Statistical Report on Internet Development in China> released by CNNIC, we obtained the utilization rate and percentage of time spent on various network behaviors, as shown in [Table 5].

[Table 5] Data Weights of Various Network Behaviors

\begin{tabular}{|c|c|c|c|c|}
\hline Network behavior & $\begin{array}{c}\text { User scale (ten } \\
\text { thousand people) }\end{array}$ & Usage rate (\%) & Usage time ratio (\%) & Data weight \\
\hline Instant messaging & 79172 & $95.6 \%$ & $15.6 \%$ & 14.9 \\
\hline search engine & 68132 & $82.2 \%$ & $2 \%$ & 1.6 \\
\hline online news & 67473 & $81.4 \%$ & $5.8 \%$ & 4.7 \\
\hline Network video & 61201 & $73.9 \%$ & $12.8 \%$ & 9.5 \\
\hline online shopping & 61011 & $73.6 \%$ & $3.0 \%$ & 2.2 \\
\hline online payment & 60040 & $72.5 \%$ & $2 \%$ & 1.5 \\
\hline Online music & 57560 & $69.5 \%$ & $8.6 \%$ & 6.0 \\
\hline Online game & 48384 & $58.4 \%$ & $5.3 \%$ & 3.1 \\
\hline Network literature & 43201 & $52.1 \%$ & $7.8 \%$ & 4.1 \\
\hline online banking & 41980 & $50.7 \%$ & $2 \%$ & 1.0 \\
\hline Travel booking & 41001 & $49.5 \%$ & $2 \%$ & 1.0 \\
\hline
\end{tabular}




\begin{tabular}{|c|c|c|c|c|}
\hline $\begin{array}{c}\text { Order takeaway } \\
\text { online }\end{array}$ & 40601 & $49.0 \%$ & $2 \%$ & 1.0 \\
\hline live streaming & 39676 & $47.9 \%$ & $5.5 \%$ & 2.6 \\
\hline Weibo & 35057 & $42.3 \%$ & $2 \%$ & 0.8 \\
\hline
\end{tabular}

According to [Table 5], generate a spider diagram of various network behavior data weights, as shown below.

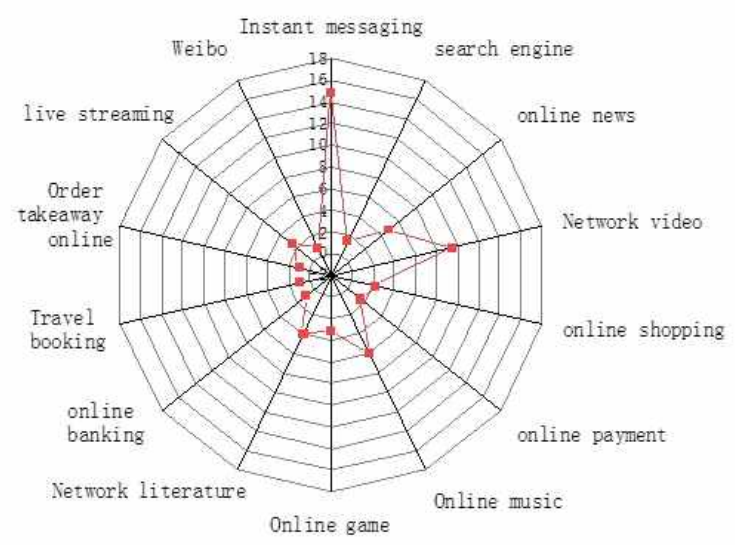

[Fig. 2] Network Behavior Data Weight

According to the above analysis, due to the relatively high usage rate and usage time ratio, the amount of data generated by instant messaging is the largest; according to [Table 4] and [Table 5], we analyze the data weight according to the dimensions of credit elements, as follows.

[Table 6] Data Weights of Various Credit Elements

\begin{tabular}{|c|c|c|}
\hline $\begin{array}{c}\text { Credit } \\
\text { factor }\end{array}$ & Network behavior & $\begin{array}{c}\text { Credit factor data } \\
\text { weight }\end{array}$ \\
\hline quality & $\begin{array}{c}\text { Instant messaging, search engines, online news, online videos, } \\
\text { online music, online games, online literature, live webcasts, } \\
\text { Weibo, online education }\end{array}$ & 47.9 \\
\hline ability & $\begin{array}{c}\text { Online shopping, online games, travel booking, online order } \\
\text { delivery, online live broadcast, online education, Internet banking }\end{array}$ & 10.8 \\
\hline capital & Online payment, online banking, Internet banking & 2.9 \\
\hline Social & $\begin{array}{c}\text { Instant messaging, online games, webcasts, Weibo, online } \\
\text { education, short videos }\end{array}$ & 28.4 \\
\hline condition & $\begin{array}{c}\text { Online shopping, travel booking, online order delivery, online } \\
\text { express or special car, online taxi, Internet banking }\end{array}$ & 6.2 \\
\hline
\end{tabular}

According to [Table 6], generate a spider diagram of the weights of various credit element 
data, as shown below.

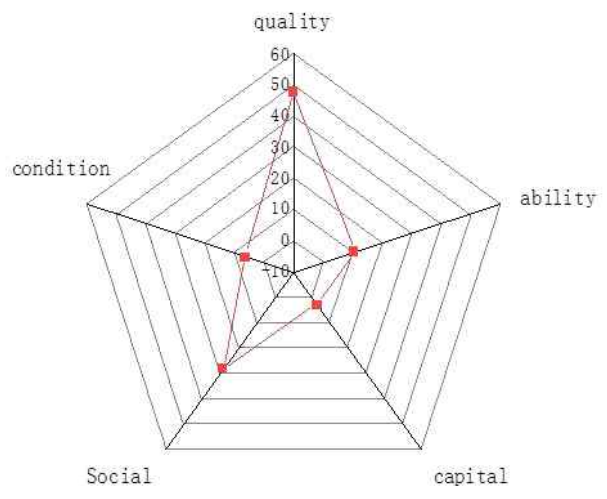

[Fig. 3] Credit Factor Data Weight

According to the above analysis, it can be seen that due to the large number of network behaviors, the data weight of the "quality" element is the largest, and the data weight of the "social" element is second only to the "quality" element, indicating that social network big data is important for personal credit .

After the data collection is completed, a reasonable data model needs to be established to make the data valuable. Let's first analyze the data models of Alibaba Credit and Tencent Credit. From the perspective of the data model, Ali's Sesame Credit score is mainly evaluated from five dimensions: identity traits, credit history, behavioral preferences, performance capabilities, and personal relationships.

(1) Identity traits: mainly consider the user's personal age, gender, marital status, occupation, family status, income level, etc.;

(2) Credit history: Mainly consider the user's personal historical credit, such as credit card repayment records, etc.;

(3) Behavioral preferences: Mainly consider the behavioral characteristics of the user's personal shopping, payment, transfer, financial management and other behaviors;

(4) Ability to perform contracts: Mainly consider the performance of individual users in various types of credit services;

(5) Network: Mainly consider the credit rating of the user's friends and the degree of interaction between the user and friends.

Tencent's credit report builds five index models of "performance, safety, wealth, consumption, and social", which are calculated based on the user's historical behavior data and comprehensive evaluation. 
(1) Security index-mainly considers the accuracy of personal information, the security of personal accounts, whether to frequently change contact information, etc.;

(2) Performance index-mainly considers the user's credit compliance, such as credit card, loans, repayment of installments; 3 . Wealth index-mainly considers personal assets;

(3) Consumption index--mainly consider users' payment behavior based on mobile QQ and WeChat;

(4) Social index - mainly considers the user's social behavior and network relationships.

According to the "5C" credit analysis model, we compare with the personal credit data models of Ali and Tencent, as shown in the following table.

[Table 7] Comparison between Ali and Tencent Data Models and "5C" Model

\begin{tabular}{|c|c|c|}
\hline $\begin{array}{l}\text { "5C" model of network } \\
\text { behavior }\end{array}$ & Ali Credit Information Data Model & $\begin{array}{c}\text { Tencent Credit Information Data } \\
\text { Model }\end{array}$ \\
\hline quality & $\begin{array}{l}\text { Identity traits, credit history, behavioral } \\
\text { preferences, performance capabilities }\end{array}$ & Safety index, performance index \\
\hline ability & $\begin{array}{l}\text { Identity traits, credit history, behavioral } \\
\text { preferences }\end{array}$ & $\begin{array}{l}\text { Performance index, consumption } \\
\text { index }\end{array}$ \\
\hline capital & $\begin{array}{l}\text { Credit history, behavioral preferences, } \\
\text { performance capabilities }\end{array}$ & Wealth index, consumption index \\
\hline Social & Connections & Social index \\
\hline condition & $\begin{array}{c}\text { Identity traits, credit history, behavioral } \\
\text { preferences }\end{array}$ & $\begin{array}{l}\text { Performance index, consumption } \\
\text { index }\end{array}$ \\
\hline
\end{tabular}

It can be seen from the table that whether it is Alibaba Credit or Tencent Credit, its data model covers all the dimensions of the " $5 \mathrm{C}$ " model; its data model has a "social" dimension, indicating that social network big data the letter has important value;

From the perspective of service scenarios, Ali's Sesame Credit mainly solves the problem of user's default risk identification in credit, leasing, transaction and other scenarios. Specific industries and usage examples are as follows:

(1) Financial industry: As a reference factor for financial risk control, such as credit or card issuance scenarios in banks, consumer credit and cash lending scenarios, Sesame has a strong ability to distinguish users' credit risks and can be used to make pass/reject decisions Reference

(2) Life scene: e-commerce shopping guide, community social networking, O2O, travel, accommodation, life, etc. For example, if the sesame score is above 600 points, there is a chance to enjoy rental deposit reduction, quick rebate, quick refund, first use and then payment; the stratification consideration of members, sesame score as a shopping credit factor affects the user's shopping rating on the e-commerce platform. 
The main credit information products of Tencent Credit Information are divided into two categories:

(1) First, serving financial institutions, Tencent Credit Reporting provides financial institutions with online big data credit reporting results to help financial institutions reduce credit risk and fraud risk;

(2) The second is to serve enterprises and individual users, use the daily transactions and social network behaviors of enterprises and individuals to establish credit records for them, and form credit rating products on this basis.

Tencent's credit investigation has already carried out credit investigation cooperation with many types of financial institutions and quasi-financial institutions such as commercial banks, consumer finance companies, small loans and P2P companies, insurance companies, financial service companies, etc. In terms of specific business processes, Tencent Credit Report provides risk management solutions for various financial institutions before, during, and after loans.

Ali and Tencent use their respective data advantages to provide their own competitive application scenario services. However, from another perspective, Ali and Tencent's big data also have their own limitations, resulting in incomplete application scenarios.

\section{Conclusion}

Based on the traditional credit analysis method, this paper builds a network behavior "5C" credit analysis method, and uses the list method and spider diagram to quantitatively analyze the value weight of network behavior big data and social network big data for personal credit. The system has studied the impact and significance of social network big data on personal credit reporting business. From the aspects of data collection, data model, data service, etc., and combined with the mainstream research theory of social network and big data, the overall analysis of social network big data is conducted. And discussion. Combining the practice of 8 individual credit reporting pilot institutions, especially Ali and Tencent, and the development of Baixing Credit Reporting, we made a complete summary and analysis of the development of my country's personal credit reporting business, and put forward constructive opinions.

\section{References}

[1] Luo Zhenzhen, Research and reform of personal credit research based on social network data, Reform and Exploration, (2017), No.5, pp.43-49, DOI:10.3969/j.issn.1003-9031.2017.05.06 
[2] Feng Wenfang, Li Chunmei, Discussion on the construction of big data credit information system in the Internet + era, Credit Information, (2015), No.10, pp.36-38.

[3] Dong Yuanxiang, Cheng Xin, Construction of personal credit evaluation system under the background of big data, Modern Industrial Economy and Informatization, (2017), Vol.7, No.5, pp.106-108, DOI: 10.16525/j.cnki.14-1362/n.2017.05.44

[4] Óskarsdóttir, María, Bravo, Cristián, Sarraute C, The value of big data for credit scoring: Enhancing financial inclusion using mobile phone data and social network analytics, Applied Soft Computing, (2018), Vol.74, pp.26-39. DOI: https://doi.org/10.1016/j.asoc.2018.10.004

[5] Liu Xinhai, Credit information and big data, China Beijing: CITIC Press, (2018).

[6] Xiaomei Y, Songyang J, The construction of big data credit evaluation system in the management of indemnificatory housing access, The $20193^{\text {rd }}$ International Workshop, (2019), June 28-30; Guilin, China.

[7] Kokula Krishna Hari Kunasekaran, Research on E-commerce Customer Loyalty under Big Data, International Journal of Advanced Research in Big Data Management System, (2020), Vol.4, No.1, pp.1-16.

[8] Pankti Joshi, Sabah Mohammed, Identifying Social Media Influencers using Graph Based Analytics, International Journal of Advanced Research in Big Data Management System, (2020), Vol.4, No.1, pp.35-44.

[9] Liu Xinhai, Application and enlightenment of big data credit investigation-taking american internet finance company zest finance as an example, Tsinghua Financial Review, (2014), No.10, pp.93-98.

[10] Xiao L, Research on the predicament and protection mechanism of personal sensitive data in china's big data credit reporting, China: Southwest Finance, (2019)

[11] Han Zhuangfei, Research on internet finance development-taking Alibaba group as an example, Henan University, Master's Thesis, (2013)

[12] Cheng Zhenyu, Research on the influence of network interaction on purchase intention and trust guarantee mechanism under social network, Beijing University of Posts and Telecommunications, Doctoral Dissertation, (2013)

[13] Jiyoung Yoon, Soonhee Joung, A Consumer Recommendation System based on Big Data, International Journal of Smart Business and Technology, (2019), Vol.7, No.2, pp.25-30.

[14] Srikanth Meda, A survey on Machine Learning Classifiers and Big data for Accurate and Reliable Heart Disease Pre-diagnosis, International Journal of Advanced Research in Big Data Management System, (2019), Vol.3, No.2, pp.23-30.

[15] Radhya Sahal, Mohamed H. Khafagy, Fatma A. Omara, Comparative Study of Multi-query Optimization Techniques using Shared Predicate-based for Big Data, International Journal of Grid and Distributed Computing, (2016), Vol.9, No.5, pp.229-240.

[16] Laouratou Diallo, Aisha Hassan Abdalla Hashim, Momoh Jimoh Eyiomika Salami, Sara Babiker Omer Elagib and Abdullah Ahmad Zarir, The Rise of Internet of Things and Big Data on the Cloud: Challenges and Future Trends, International Journal of Future Generation Communication and Networking, (2017), Vol.10, No.3, pp.49-56. 